\title{
DETERMINAN KEPATUHAN IBU HAMIL MELAKUKAN PEMERIKSAAN KEHAMILAN
}

\author{
Dini Afriani ${ }^{1}$, Erlin Merlina ${ }^{2}$ \\ 1,2) Program S1 Kesehatan Masyarakat \\ Sekolah Tinggi Ilmu Kesehatan Sebelas April Sumedang \\ bydiniaf@gmail.com
}

\begin{abstract}
ABSTRAK
Pemeriksaan kehamilan (Antenatal Care) adalah pemeriksaan kehamilan berupa penanganan medis, observasi dan penyuluhan kepada ibu yang sedang hamil bertujuan untuk memastikan ibu hamil menjalani kehamilan yang sehat dan mampu mempersiapkan persalinannya. Pemeriksaan kehamilan dapat dilakukan di Praktik Mandiri Bidan, Puskesmas, klinik, atau rumah sakit. Metode Penelitian ini menggunakan metode kuantitatifnon eksperimen, survei analitik dengan cross-sectional. Penelitian dilaksanakan pada bulan April 2020 di Puskesmas Sukagalih Sumedang dengan menggunakan teknik sampling yaitu total sampling dengan populasi sebanyak $46 \mathrm{ibu}$ hamil. Pengumpulan data diperoleh dengan menggunakan kuesioner yang sudah di adaptasi dari penelitian orang lain terkait kepatuhan ibu hamil melakukan pemeriksaan kehamilan. Hasil penelitian menunjukan bahwa dari tiga variable yang diteliti diketahui yang berhubungan dan bermakna secara statistik ( $p$-value $<0,05)$ dengan kepatuhan ibu hamil trimester III dalam pemeriksaan kehamilan yaitu variable pengetahuan $(p$-value $=0,009)$, dukungan petugas kesehatan $(p$-value $=(0,001)$. Sedangkan yang tidak berhubungan dengan kepatuhan pemeriksaan kehamilan pada ibu hamil trimester III yaitu variable umur ( $p$-value $=0,093$ ). Berdasarkan hasil penelitian diatas diharapkan Puskesmas Sukagalih dapat meningkatkan promosi kesehatan dan melakukan kegiatan kontak lanjutan seperti Posyandu hingga ibu hamil bisa melakukan pemeriksaan kehamilan secara berkala dan mengetahui pentingnya pemeriksaan kehamilan dilakukan oleh ibu hamil trimester III.
\end{abstract}

Kata kunci : kepatuhan ibu hamil, pemeriksaan kehamilan, trimester III.

\section{Abstract}

Antenatal Care is pregnancy care in medical treatment, observation and counselling for pregnant women to ensure that pregnant women have healthy pregnancies and can prepare for labour. Pregnancy checks can be done at the Midwife's Practice, Puskesmas, clinics, or hospitals. Methods This research uses non-experimental quantitative methods, the analytic survey with a cross-sectional. The research was conducted in April 2020 at the Sukagalih Sumedang Community Health Center using the sampling technique, namely total sampling with a population of 46 pregnant women. Data collection obtained using a questionnaire based on other research related to pregnant women based on pregnancy. The results showed that of the three variables studied, it does know that those related and statistical ( $p$-value $<0.05)$ with the entry of thirdtrimester pregnant women in pregnancy were knowledge variables ( $p$-value $=0.009)$, support from health workers $(p$-value $=(0.001))$. Not related to pregnancy in third trimester pregnant women, namely the variable age $(p=0.093)$. Based on the research results, it is expected that Sukagalih Puskesmas can increase health promotion and carry out further contact activities such as Posyandu to pregnant women who can carry out periodic checks and see pregnancy pregnancies pregnancy by trimester III pregnant 
women.

Keywords: compliance of pregnant women, antenatal care, trimester III

\section{PENDAHULUAN}

Angka Kematian Ibu (AKI) adalah salah indikator untuk mengetahui keberhasilan upaya peningkatan kesehatan ibu. AKI merupakan satu rasio kematian ibu selama masa kehamilan, persalinan dan nifas yang disebabkan oleh kehamilan, persalinan dan nifas dan cara mengatasinya, namun bukan karena sebab-sebab lain seperti kecelakaan atau terjatuh.

Pada penelitian di Tigray, Ethiopia tahun 2017 berjudul Tingkat kepatuhan ibu hamil melakukan kunjungan pemeriksaan di Institusi Kesehatan Masyarakat Tigray oleh Abera Haftu dkk. Hasil penelitiannya sebanyak 1103 perempuan direkrut dan 100\% di antaranya ditindaklanjuti hingga enam minggu pascapersalinan dari Desember 2017 hingga Juli 2018. Hasil penelitiannya yaitu kelompok intervensi menunjukkan peningkatan yang signifikan dalam pengetahuan dan perilaku tentang kesehatan ibu dan keluarga berencana dibandingkan dengan kelompok pembanding ( $p$-value <0,001). Secara khusus, terjadi peningkatan dramatis dari 10,8\% menjadi 93,5\% pada angka kelahiran di institusi pada kelompok intervensi terkait ibu pengetahuan ibu hamil yang melakukan pemeriksaan kehamilan.(Haftu et al., 2018).

Menurut Wagiyo \& Putrono (2016), Kebijakan program pelayanan asuhan antenatal harus sesuai standar yaitu "14 T" meliputi: timbang berat badan (T1) ukur berat badan dalam kilo tiap kali kunjungan. Kenalkan berat badan normal pada waktu hamil $0,5 \mathrm{~kg}$ per minggu mulai trimester kedua. Ukur tekanan darah (T2), tekanan darah yang normal 110/80 hingga 140/90 mmHg, bila melebihi dari 140/90 $\mathrm{mmHg}$ perlu diwaspadai adanya preeklampsia. Ukur tinggi fundus uteri (T3) dan pemberian tablet Fe sebanyak 90 tablet selama kehamilan (T4). Pemberian imunisasi (T5), Pemeriksaan $\mathrm{Hb}$ (T6) dan Pemeriksaan VDRL (T7). Perawatan payudara, senam payudara, dan pijat tekan payudara (T8). Pemeliharaan tingkat kebugaran atau senam ibu hamil (T9), temu wicara dalam rangka persiapan rujukan (T10). Pemeriksaan protein urine atas indikasi (T11). Pemeriksaan reduksi urine atas indikasi (T12). Pemberian terapi kapsul yodium untuk daerah endemis gondok (T13). Pemberian terapi anti-malaria untuk daerah endemis malaria (T14).(Wagiyo, Ns, 2016)

Standar kunjungan pelayanan pemeriksaan antenatal care pada ibu hamil yaitu paling sedikit 4 kali kunjungan selama masa kehamilan. (Kemenkes RI, 2018). Setiap wanita hamil menghadapi resiko komplikasi yang bisa mengancam jiwanya. Oleh karena itu, wanita hamil perlu melakukan kunjungan kehamilan sedikitnya empat kali kunjungan selama masa kehamilan: satu kali kunjungan selama trimester satu ( $<14$ minggu). Pada kunjungan ini melakukan tindakan pencegahan seperti tetanus neonatorum, anemia kekurangan zat besi serta mendorong perilaku yang sehat (gizi, latihan, kebersihan, istirahat dan sebagainya). Satu kali kunjungan selama trimester kedua (antara minggu 14-28). Pada kunjungan ini pemeriksaannya sama dengan sebelumnya, ditambah kewaspadaan khusus mengenai preeklamsi (gejala preeklampsia, pemantauan tekanan darah, evaluasi adanya edema). Dua kali kunjungan selama trimester ketiga (antara minggu 28-36 dan sesudah minggu ke 36). Pada pemeriksaan trimester tiga antara minggu 28-36 ini ditambah pemeriksaan palpasi abdominal untuk mengetahui ada atau tidaknya kehamilan ganda. Setelah minggu ke 36 di tambah deteksi letak bayi yang tidak normal 
atau kondisi lain yang memerlukan kelahiran di rumah sakit. (Kemenkes RI, 2018).

Berdasarkan data Puskesmas Sukagalih pada tahun 2018 yang melakukan kunjungan ibu hamil keseluruhan berjumlah 427 orang sedangkan yang melakukan K1 cakupannya yaitu mencapai $(102,4 \%)$ dan K4 cakupannya yaitu mencapai (127,0\%). Adapun Puskesmas yang cakupannya paling rendah terkait dengan $\mathrm{K} 1$ dan K4 dengan pada tahun 2018 yaitu Puskesmas Jatigede cakupan K1 (68,1\%) dan cakupan K4 mencapai (84,1\%), Puskesmas Tanjungkerta cakupan K1 mencapai (87,0\%) dan cakupan K4 mencapai (117\%) sedangkan Puskesmas Buahdua cakupan K1 mencapai (79,3\%) dan cakupan K4 mencapai (99,8\%). (Dinas Kesehatan Provinsi Jawa Barat, 2019).

Berdasarkan Profil Puskesmas Sukagalih tahun 2019 yang melakukan kunjungan ibu hamil trimester III berjumlah 46 orang. Cakupan pemeriksaan ibu hamil tiap tahun meningkat tetapi penilaian cakupan program masih dibawah target, adapun Target Pencapaian Program K1 Puskesmas Sukagalih untuk tahun 2019 adalah $100 \%$. Bila melihat jumlah presentasi total Puskesmas Sukagalih tahun 2019 adalah 98,29\% belum mencapai target dan terjadi kesenjangan $-1,71 \%$. Target Pencapaian K4 Puskesmas Sukagalih tahun 2019 adalah $96,50 \%$, bila melihat jumlah presentase total Puskesmas Sukagalih tahun 2019 belum mencapai target 94,62\% dan terjadi kesenjangan -1,88\%. Dapat diketahui dari hasil studi pendahuluan dengan bidan desa pada tanggal 02 April tahun 2020 melalui wawancara terdapat $10 \mathrm{ibu}$ hamil, muncul $6 \mathrm{ibu}$ hamil yang datang kunjungan pemeriksaan kehamilan secara berkala dan datang $4 \mathrm{x}$ seperti jadwal yang ditentukan. Sedangkan terdapat 4 ibu hamil melakukan pemeriksaan kehamilan kurang dari 4x tidak sesuai seperti jadwal pemeriksaan kehamilan bahkan tidak datang pemeriksaan kehamilan sama sekali karena berbagai faktor. Faktor-faktor tersebut diantaranya kehamilan yang tidak diinginkan seperti hamil diluar nikah, usia ibu sudah tua, kesalahan memakai alat kontrasepsi dan pengetahuan yang kurang. Penelitian ini bertujuan untuk mengetahui adanya gambaran kepatuhan ibu hamil dalam melakukan pemeriksaan kehamilan, adanya hubungan antara umur, pengetahuan, dukungan tenaga kesehatan terhadap kepatuhan ibu hamil melakukan pemeriksaan kehamilan.

\section{METODOLOGI}

Jenis penelitian ini menggunakan metode pendekatan kuantitatif dengan non eksperimental, dengan rancangan cross-sectional. (Notoatmodjo, 2013).

Dalam penelitian ini jumlah sample merupakan total sampling yaitu semua ibu hamil dengan Trimester III di wilayah kerja Puskesmas Sukagalih Kabupaten Sumedang, yaitu sebanyak 46 orang.

\section{Instrumen Penelitian}

Instrumen penelitian ini menggunakan Kuesioner (daftar pertanyaan). Kuesioner pada peneliti gunakan sudah meminta ijin pada peneliti untuk diadopsi pada kuesioner yang telah ada yaitu kuesioner pada penelitian Vio Nita (2017) yang berjudul Faktor Yang Terkait Dengan Frekuensi Kunjungan Antenatal Care (ANC) di Provinsi Yogyakarta Pusat Kesehatan Masyarakat Mergangsan Tahun 2014. (Nita, 2017).

\section{Uji validitas dan reliabilitas}

Dalam penelitian ini menggunakan kuesioner yang sudah ada dan baku untuk digunakan dalam penelitian, maka tidak lagi melakukan uji validitas dan reliabilitas. (Arikunto, 2013). 


\section{Analisis Data}

Analisis univariat dikerjakan pada tiap variabel hasil penelitian bertujuan mengetahui gambaran frekuensi distribusi pada tiap variabel.

Analisis bivariat yaitu untuk mencari hubungan terhadap dua variabel. Metode yang dipakai untuk melihat hubungan kedua variabel tersebut memakai Uji Statistik Chi-Square berfungsi membandingkan frekuensi observasi dengan nilai frekuensi harapan sama (Sugiyono, 2013).

\section{HASIL}

Analisis Univariat

\section{Analisis Bivariat}

Tabel 2. Hubungan antara Umur dengan Kepatuhan Pemeriksaan Kehamilan

\begin{tabular}{|c|c|c|c|c|c|c|c|}
\hline \multirow{3}{*}{ Umur } & \multicolumn{6}{|c|}{ Kepatuhan Pemeriksaan Kehamilan } & \multirow{3}{*}{ p-value } \\
\hline & \multicolumn{2}{|c|}{ Tidak Patuh } & \multicolumn{2}{|c|}{ Patuh } & \multicolumn{2}{|c|}{ Jumlah } & \\
\hline & f & $\%$ & $\mathbf{f}$ & $\%$ & $\mathbf{n}$ & $\%$ & \\
\hline Tidak Beresiko (20-35 tahun) & 2 & 7,1 & 26 & 92,9 & 28 & 100 & \multirow{2}{*}{0,093} \\
\hline Beresiko ( $<20$ dan $\geq 35$ tahun $)$ & 5 & 27,8 & 13 & 72,2 & 18 & 100 & \\
\hline Total & 7 & 15,2 & 39 & 84,8 & 46 & 100 & \\
\hline
\end{tabular}

Tabel 3. Hubungan antara Pengetahuan dengan Kepatuhan Pemeriksaan Kehamilan

\begin{tabular}{|c|c|c|c|c|c|c|c|}
\hline \multirow{3}{*}{ Pengetahuan } & \multicolumn{6}{|c|}{ Kepatuhan Pemeriksaan Kehamilan } & \multirow{3}{*}{ p-value } \\
\hline & \multicolumn{2}{|c|}{ Tidak Patuh } & \multicolumn{2}{|c|}{ Patuh } & \multicolumn{2}{|c|}{ Jumlah } & \\
\hline & f & $\%$ & $\mathbf{f}$ & $\%$ & $\mathbf{n}$ & $\%$ & \\
\hline Kurang Baik & 3 & 75,0 & 1 & 25,0 & 4 & 100 & \multirow{2}{*}{0,009} \\
\hline Baik & 4 & 9,5 & 38 & 90,5 & 42 & 100 & \\
\hline Total & 7 & 15,2 & 39 & 84,8 & 46 & 100 & \\
\hline
\end{tabular}

Tabel 4. Hubungan antara Dukungan Petugas Kesehatan dengan Kepatuhan Pemeriksaan Kehamilan

\begin{tabular}{|c|c|c|c|c|c|c|c|}
\hline \multirow{3}{*}{ Dukungan Petugas Kesehatan } & \multicolumn{6}{|c|}{ Kepatuhan Pemeriksaan Kehamilan } & \multirow{3}{*}{ p-value } \\
\hline & \multicolumn{2}{|c|}{ Tidak Patuh } & \multicolumn{2}{|c|}{ Patuh } & \multicolumn{2}{|c|}{ Jumlah } & \\
\hline & f & $\%$ & f & $\%$ & $\mathbf{n}$ & $\%$ & \\
\hline Kurang Baik & 4 & 80,0 & 1 & 20,0 & 5 & 100 & \multirow{2}{*}{0,001} \\
\hline Baik & 3 & 7,3 & 38 & 92,7 & 42 & 100 & \\
\hline Total & 7 & 15,2 & 39 & 84,8 & 46 & 100 & \\
\hline
\end{tabular}




\section{PEMBAHASAN}

\section{Distribusi frekuensi kepatuhan pemeriksaan kehamilan}

Menurut peneliti, ibu yang patuh datang hadir pemeriksaan kehamilan akan mendapatkan akses lebih mudah dalam menerima edukasi dan informasi tentang melindungi kehamilan, mendapatkan bantuan yang lebih cepat dalam memecahkan masalah apabila kehamilan yang tidak sesuai dengan seharusnya dan mendapatkan pelayanan kesehatan yang mudah, sehingga ibu tergolong orang yang tetap menjaga kehamilan yang sehat dan terdorong untuk datang kunjungan kehamilan secara berkala.

\section{Hubungan antara umur dengan kepatuhan pemeriksaan kehamilan}

Hasil penelitian ini mendapatkan hasil yang sama dengan penelitian Armaya (2018) yang berjudul kepatuhan ibu dalam melakukan antenatal care dan faktor yang mempengaruhi bahwa sebagian besar responden penelitian berada pada usia reproduksi yang sehat untuk hamil yaitu umur 20-35 tahun sebanyak 42 orang ibu (76,4\%).(Armaya, 2018).

Menurut teori umur sebagai unsur biologis yang menunjukkan tingkat kematangan manusia, terutama pada organ-organ perseptual sehingga persepsi dapat berlangsung. Umur akan mempengaruhi jiwa seseorang yang menerima mengolah kembali pengertian -pengertian atau tanggapan, sehingga dapat dilihat bahwa semakin tinggi usia seseorang, maka proses pemikirannya lebih matang,biasanya orang muda pemikirannya radikal sedangkan orang dewasa lebih moderat. (Sarwono, 2014).

Menurut asumsi peneliti, bahwa umur tidak bisa dijadikan patokan untuk seseorang melakukan pemeriksaan kehamilan. Karena berapapun umur ibu hamil akan tetapi dengan ketidaktahuan, tidak adanya keluhan, dengan tidak adanya edukasi tentang kehamilan ataupun menganggap pemeriksaan kehamilan cenderung acuh terhadap pemeriksaan kehamilan karena merasa telah memiliki pengalaman yang baik. Sehingga peneliti menyimpulkan umur tidak ada kaitannya dengan kepatuhan pemeriksaan kehamilan (ANC).

\section{Hubungan antara pengetahuan dengan kepatuhan pemeriksaan kehamilan}

Hasil penelitian ini sejalan dengan dengan penelitian tamaka yang dengan keteraturan pemeriksaan antenatal care di puskesmas bahu kecamatan malalayang kota manado tahun 2013" (Tamaka et al., 2013).

Sesuai dengan teori Pengetahuan merupakan indikator seseorang dalam melakukan suatu tindakan. Tingkat pengetahuan seorang ibu hamil mengenai pentingnya pelayanan antenatal dalam mencegah dan mendeteksi secara dini masalah kesehatan obstetri, mempengaruhi pola berpikirnya tentang kunjungan ANC. Bagi ibu yang yang memiliki tingkat pengetahuan yang tinggi, kunjungan antenatal bukanlah sekadar untuk memenuhi kewajiban, melainkan menjadi sebuah kebutuhan. Sehingga semakin tinggi tingkat pengetahuan ibu hamil, maka semakin tinggi pula frekuensi kunjungan ANC yang dilakukan.(Sarwono, 2014).

Menurut peneliti, hasil penelitian ini terdapat hubungan antara pengetahuan dengan kepatuhan pemeriksaan kehamilan. Ibu hamil trimester III yang memiliki pengetahuan baik telah terbukti melakukan sering melakukan pemeriksaan kehamilan secara berkala kepada tenaga kesehatan. Namun sebaliknya ibu hamil trimester III yang memiliki pengetahun kurang baik karena tidak melakukan pemeriksaan kehamilan mungkin kurang mengetahui tentang pengetahuan tersebut dan kurangnya informasi pada pengetahuan pemeriksaan kehamilan tersebut. 


\section{Hubungan antara dukungan petugas kesehatan dengan kepatuhan pemeriksaan kehamilan}

Hasil penelitian ini sejalan dengan hasil penelitian yang dilakukan oleh susanto 2016 yang berjudul faktor yang berhubungan dengan pemeriksaan antenatal care, ibu hamil mendapatkan dukungan petugas kesehatan untuk memeriksakan kehamilannya atau pemeriksaan antenatal care di pelayanan kesehatan sebanyak 81 responden, sedangkan 12 responden tidak mendapatkan dukungan petugas kesehatan terhadap pemeriksaan Antenatal Care di pelayanan kesehatan. (Susanto et al., 2016).

Hal ini sesuai dengan teori pelayanan kesehatan, jika fasilitas baik akan mempengaruhi kesehatan, hal ini terbukti seseorang dapatmemanfaatkan fasilitas kesehatan secara baik akan mempunyai taraf kesehatan yang lebih baik. Hal ini akan membuat individu merasa bertanggungjawab terhadap kesehatannya.

Menurut peneliti, bahwa dukungan petugas kesehatan sangat berhasil dalam meningkatkan kepatuhan ibu hamil dalam melakukan pemeriksaan kehamilan, orang yang sering memeriksa kandungan dan sering berinteraksi dengan ibu hamil dan memberikan edukasi/informasi (KIE) tentang kehamilan. Sehingga ibu hamil lebih cenderung mengikuti pengarahan dari bidan desa serta dapat memotivasi pada ibu hamil.(Sarwono, 2014).

\section{SIMPULAN DAN SARAN}

Berdasarkan hasil penelitian, maka dapat ditarik kesimpulan :1) Ibu hamil lebih besar dalam kategori umur tidak beresiko (20-35 tahun); 2) Pengetahuan ibu hamil lebih besar dalam kategori baik; 3) Ibu hamil lebih besar dalam kategori baik mendapat dukungan dari petugas kesehatan; 4) Kepatuhan ibu hamil trimester III dalam melakukan pemeriksaan kehamilan yaitu sebagian besar ibu hamil trimester III lebih banyak dalam kategori patuh melakukan pemeriksaan kehamilan; 5) Dari 3 variabel yang diteliti yang berhubungan dengan kepatuhan ibu dalam pemeriksaan kehamilan adalah variabel pengetahuan, dukungan petugas kesehatan dan dukungan.

Dari hasil penelitian ini diharapkan dapat dilakukan pengembangan antara lain : memberikan pengetahuan dan solusi bagi pihak Puskesmas terkait kepatuhan pemeriksaan ANC khususnya pada setiap trimester pada kehamilan, agar persiapan kehamilan dan persalinan yang sehat dan aman. Selain itu, hendaknya informasi dan edukasi mengenai pentingnya kepatuhan pemeriksaan ANC, agar memotivasi dan memberikan dukungan kepada masyarakatnya pentingnya periksa kehamilan.

\section{DAFTAR PUSTAKA}

Arikunto, S. (2013). Prosedur penelitian : Suatu Pendekatan Praktik. Rineka Cipta.

Armaya, R. (2018). Kepatuhan Ibu Hamil dalam Melakukan Kunjungan Antenatal Care dan Faktor yang Mempengaruhi. Jurnal Ilmu Kesehatan Masyarakat. https://doi. org/10.33221/jikm.v7i01.51

Dinas Kesehatan Provinsi Jawa Barat. (2019). Profil Kesehatan Jawa Barat Tahun 2019. In Journal of Chemical Information and Modeling.

Haftu, A., Hagos, H., Mehari, M.-A., \& G/her, B. (2018). Pregnant women adherence level to antenatal care visit and its effect on perinatal outcome among mothers in Tigray Public Health institutions, 2017: cohort study. BMC Research Notes. https://doi.org/10.1186/s13104-0183987-0

Kemenkes RI. (2018). Pentingnya Pemeriksaan Kehamilan (ANC) di Fasilitas Kesehatan. Direktorat Promosi Kesehatan Dan Pemberdayaan 
Masyarakat.

Nita, V. (2017). Factors Associated With

Frequency Of Visits Antenatal

Care (Anc) In Yogyakarta Province

Mergangsan Public Health Centre.

Jurnal Medika Respati, Vol. 12 No.

Notoatmodjo, S. 2010. M. P. K. J. : R. C.

(2013). Notoatmodjo, S. 2010.

Metodologi Penelitian Kesehatan.

Jakarta : Rineka Cipta. In Journal of

Chemical Information and Modeling.

Sarwono. (2014). Ilmu Kebidanan. PT Bina

Pustaka.

Sugiyono. (2013). Metode penelitian pendidikan

pendekatan kuantitati, kualitatif, dan

$R \& D$. Alfabeta.
Susanto, J., Ahmad, L., \& Ismail, C. (2016). Faktor Yang Berhubungan Dengan Pemeriksaan Antenatal Care (Anc) Kunjungan 1 - Kunjungan 4 (K1 - K4) Pada Ibu Hamil Di Rsud Kota Kendari Tahun 2016. Jurnal Ilmiah Mahasiswa Kesehatan Masyarakat Unsyiah.

Tamaka, C., Madianung, A., \& Sambeka, J. (2013). Hubungan Pengetahuan Ibu Hamil Dengan Keteraturan Pemeriksaan Antenatal Care Di Puskesmas Bahu Kecamatan Malalayang Kota Manado. Jurnal Keperawatan UNSRAT.

Wagiyo, Ns, P. (2016). No TitleAsuhan keperawatan antenatal, intranatal, dan bayi baru lahir fisiologis dan patologis. CV Andi. 
